\title{
Disremembering 1798?
}

\author{
An Archaeology of Social Forgetting and \\ Remembrance in Ulster
}

\section{Guy BeINer}

On the face of it, the legacy of the 1798 rebellion in the northeastern Irish counties of Antrim and Down seems to be a paradigmatic case of "collective amnesia." Over the course of the long nineteenth century, growing identification of the Protestants of the area with unionism, loyalism and Orangeism, fortified through opposition to the rise of nationalism amongst Catholics, encouraged public effacement of discomforting memories of the mass participation of Protestants, in particular Presbyterians, in republican insurrection. However, the uncovering of a "hidden" (or perhaps relatively low-profile) popular historiography grounded in oral traditions reveals continuous obsessive, though characteristically ambivalent, local preoccupation with remembrance of the rebellion. Acknowledging that forgetting is not the antithesis, but an integral component, of memory, this case study of what appears to be an Ulster lieu d'oubli conceptualizes "social forgetting" as the outcome of multi-layered relationships between oblivion and remembering.

\section{ADVOCATING FORGETTING}

In 1898, as Irish nationalists of all hues and shades were enthusiastically engaged in remembering 1798 through massive commemorations of the centennial of the United Irish Rebellion, in the northern province of Ulster, the Orange Order, an organization dedicated to "Glorious and Immortal Memory," was preoccupied with forgetting. On May 20, 1898, the Reverend Dr. Richard Rutledge Kane—a pillar of local unionist politics—addressed a large and enthusiastic audience at Clifton Street Orange Hall in Belfast with a lecture on "1798: Its Lessons for Irishmen." Renowned as a fiery 
orator, "Roaring Kane" was no stranger to commemoration. As Grand Master of the Orange Order in Belfast since 1885, he had presided over annual anniversaries of the Twelfth of July (commemorating the victory of William III over James II at the Battle of the Boyne in 1690), where he regularly bellowed the imperative to remember the past. But when it came to the "very painful and melancholy story" of the 1798 rebellion, he noted that it was "a subject full of the most painful memories" and that it would be best to "rather have that terrible year forgotten and forgiven."

Dr. Kane was not alone amongst Ulster unionists in advocating oblivion. Earlier that month, another prominent Orangeman-Reverend Dr. R. S. O'Loughlin, the rector of the Church of Ireland parish of Shankill, spoke at Belfast's Queen Victoria Hall on "1798 in Ireland," a topic he had previously addressed in a lecture at his home church in Lurgan (March 28, 1898), which was considered sufficiently important to be reproduced in the local press and distributed as a penny pamphlet. ${ }^{2}$ He maintained that "no party in it was blameless; that many sad and bitter memories were connected with it, and that it would be well for the nation if they could safely be forgotten." 3 These views were echoed in a poem by a member of a local Orange lodge (L.O.L. 247) published in the Belfast News-Letter:

Turn Down the pages of the story,

Blot out its blood with tears,

May its rancour be all forgotten,

In the peace of the coming years. ${ }^{4}$

Asserting that Dr. Kane's sentiments were "shared by all loyal Irishmen," the unionist press put forward the dictum that "Ulster wants to forget it all, because Ulster is not proud of the rebellion, and Ulster is loyal." 5

Whereas it may appear self-evident that loyalists would object to nationalist commemoration of rebellion, these passionate pleas for deliberate forgetting, primarily addressed to their own constituency, indicate, as this article will demonstrate, that there was something deeper at play. Rather than choosing to ignore the anniversary of 1798 or to be satisfied with condemning its celebration, the compulsion to discuss the topic and to emphatically argue that it should be forgotten marked an obsessive preoccupation with the rebellion and an attempt to iron out its embarrassing legacies. Over the previous century, a tradition of loyalist polemics, 
stemming from Sir Richard Musgrave's Memoirs of the Different Rebellions in Ireland (originally published in 1801), focused almost exclusively on the rebellion in the southwestern county of Wexford-mostly overlooking Ulster-in order to construe the events of 1798 as a sectarian jacquerie. ${ }^{6}$ This partisan interpretation corresponded to a well-rehearsed litany of Catholic treachery and atrocities, which formed the backbone of an ingrained tradition of Protestant-loyalist memory. ${ }^{7}$ The 1798 rebellion in northeast Ulster, with its predominance of Presbyterians amongst the insurgents and their participation in insurrection alongside Catholics, as well as some Protestants of the established church, complicated matters. ${ }^{8}$ The directive to forget was therefore a conscious attempt to exorcise the ghosts of a discomfiting communal past, which ill suited the polarized politics of the present and was incongruous with what had become the dominant Irish Protestant collective memory. ${ }^{9}$

It is apparently psychologically possible to instigate "intentional forgetting." 10 That said, there is a distinct difference, sociologically, between prescribed forgetting and actual forgetting. The marking of certain recollections for disregard paradoxically identifies them as an object of particular curiosity. Evasion, or contrived silence, as discussed in an insightful treatise by Eviatar Zerubavel, only renders the deliberately unmentioned "elephant in the room" even more conspicuous. ${ }^{11}$ The well-known gag "don't mention the war," popularized in a memorable episode of the English television comedy Fawlty Towers, actually makes a serious point, insofar as the tragicomic outcome of the sketch illustrated how overstated anxieties of addressing a troublesome historical episode often result in inevitable confrontation with the past. ${ }^{12}$ Likewise, repeated advocacy of the necessity to forget 1798 ironically signifies an engagement with its ambiguities. A historical examination of the manifestations of the uneasy engagement with the legacy of "Ninety-Eight" (the name frequently accorded to that fatal year) in Ulster offers a case study for the conceptualization of "social forgetting" as a specific, particularly problematic, mode of social memory, which hinges on multilayered dialectical relationships between oblivion and remembrance. 


\section{CONTEXTS OF DISREMEMBERING}

Back in the late eighteenth century, when Irish Presbyterians of Scottish descent-commonly referred to as Dissenters-were known for their radicalism, their concentrated areas of settlement in northeast Ulster became a hotbed of revolutionary activities. ${ }^{13}$ In 1791 and ' 92 , self-styled Irish Jacobins jubilantly commemorated the anniversaries of the fall of the Bastille in the streets of Belfast and Tom Paine's Rights of Man was hailed "the Koran of Blefescu." 14 This politically charged environment would produce the subversive Society of the United Irishmen. Its principle organ The Northern Star (established in 1792 and suppressed in 1797) was widely distributed by subscription in Ulster and read throughout the highly literate province. ${ }^{15}$ Theobald Wolfe Tone (later regarded as the "Father of Irish Republicanism") assembled in 1795 a core group of Protestant radicals_-including Ulstermen Robert Simms, Samuel Neilson and Henry Joy McCracken, as well as local resident Thomas Russell-at McArt's Fort on the summit of Cave Hill, above Belfast. Overlooking the town, they swore a "solemn obligation," undertaking "never to desist in our efforts, until we have subverted the authority of England over our country and asserted her independence," a symbolic proclamation that marked the transition of the United Irishmen from a reformist movement to a revolutionary organization. ${ }^{16}$ Recruitment to the United Irishmen was widespread in the surrounding counties of Antrim and Down, with local membership approaching 50,000 by mid-1797. ${ }^{17}$

Seditious mass mobilization persisted even in spite of heavy battering sustained in 1797 from the "dragooning" of Ulster under General Gerard Lake, who was responsible for stringent counterinsurgency measures aimed at nipping in the bud the possibility of a popular uprising. ${ }^{18}$ Following the advance arrests of key leaders, the uprisings in counties Antrim and Down were short and bloody affairs, which lasted a mere week in June 1798. The military secured Belfast with reinforcements, preventing it from taking part in revolt, but large-scale engagements took place at Antrim town (June 7 ) and at Ballynahinch, County Down (June 13), alongside smaller insurrectionary incidents throughout the two counties and their environs. ${ }^{19}$ All in all, northeast Ulster was a major arena of the 1798 rebellion, the most lethal outburst of violence in modern Irish history. 
Inspired by the ideals of the French Revolution, the ultimate aspiration of the United Irishmen, in the words of Wolfe Tone, had been "to break the connexion with England" and to establish an independent republic, which would "substitute the common name of Irishman in place of the denominations of Protestant, Catholic, and Dissenter." ${ }^{20}$ The administration in Dublin Castle set its sights on disrupting this radical fraternity, which challenged the status quo of Anglo-Irish Protestant ascendancy and the dominance of the British crown. Accordingly, conservative propaganda in 1798 attempted to sow discord within the United Irish camp by spreading news of sectarian atrocities perpetrated by Catholics in the south with the intent of discouraging disaffected northern Protestants and winning over their loyalty. Substantial numbers of Presbyterians disassociated themselves from the rebels and some actively opposed the rebellion. In the wake of the insurrection's failure - in a trend locally labeled "mushroom loyalty"many rehabilitated Presbyterians renounced their rebel ties, issuing public declarations of loyalty and actively demonstrating their newfound loyalism by joining the yeomanry (a loyalist paramilitary force), some even entering the vehemently anti-Catholic Orange Order. ${ }^{21} \mathrm{~A}$ year after the rebellion, the chief secretary (head of the executive administration in Dublin Castle) Lord Castlereagh, himself an Ulsterman who had formerly been associated with liberal-reformist Presbyterian circles, overconfidently noted: "the Protestant Dissenters in Ulster have in a great degree withdrawn themselves from the Union [i.e. the United Irishmen], and become Orangemen." 22

In contrast to the United Irish separatist republican program, the British solution to the Irish problem was to enact a legislative union between the two kingdoms, on the model of the union with Scotland in 1707. As the success of this initiative depended on its ratification in the exclusively Protestant Irish parliament (which effectively had to abolish itself in return for representation in Westminster), concerted efforts were made to solicit local Protestant support. Touring the north of Ireland in October 1799, the Lord Lieutenant (the English viceroy in Ireland) Marquis Cornwallis was delighted to have been "received with open arms at Belfast" and to discover that in the recently rebellious county Antrim "the cry for an Union is almost unanimous." ${ }^{23}$ A majority of members of parliament representing the Presbyterian-dominated constituencies of counties Antrim, Down and Londonderry indeed voted for the Act of Union, which came into effect on January 1, 1801, with the establishment of the 
United Kingdom of Great Britain and Ireland. ${ }^{24}$ The desire to instill a new unionist identity among northern Protestants required the obliteration of the locality's previous reputation as a cradle of revolution. The rapid decline in radical zeal was manifest at the time of Robert Emmet's failed attempt at insurrection in 1803, when his northern emissaries Thomas Russell, James Hope and William Henry Hamilton traversed the former United Irish Presbyterian heartland in an effort to foment popular support but were ultimately unsuccessful in rekindling rebellion..$^{25}$ It would seem that following the routing of the rebels in the summer of 1798 , the spirit of republicanism was quelled in Ulster.

Upon further inspection, the appearance of a smooth and swift mass conversion from republicanism to unionism in the immediate aftermath of the 1798 rebellion may conceal a more complicated reality. Internal rifts in the General Synod of Ulster, marked by presbyteries taking opposing stances on the issue of the union with England, offer an indication that the influence of radical Presbyterian ministers, who harbored sympathies for the ideals of the United Irishmen, had not yet lapsed. ${ }^{26}$ Moreover, local pockets of sedition remained unpacified. Eight months after the rebellion, Cornwallis was still concerned with continued insurgency in northeast Ulster, noting "there is reason to believe that parts of the counties of Down and Antrim are again ready for insurrection." ${ }^{27}$ Even after the passing of the Act of Union, he voiced concern that "the county of Antrim is much agitated and convulsed by bandittis [sic] of robbers." ${ }^{28}$ It was only half a year later that he could report to the home secretary, the Duke of Portland, that the "partial disturbances, rather of an alarming nature" appeared to have subsided. ${ }^{29}$ This observation may be an overstatement, as an in-depth study has uncovered evidence of disaffection in Antrim and Down continuing well into $1804 .^{30}$

Shattered by the brutality that they had experienced in 1798, many disillusioned Presbyterians subsequently disassociated themselves from politics. ${ }^{31}$ In the public sphere, Presbyterian communities that had been heavily implicated in the failed republican rebellion gradually realigned their political allegiances over the course of the nineteenth century. ${ }^{32}$ Notwithstanding the prominence of liberal civic unionism among Belfast's moderate Presbyterians who remained estranged from Toryism, ${ }^{33}$ as a whole, Protestant Ulster became identified as a bastion of militant unionism and Orangeism, fronting staunch opposition to the rise of Irish nationalism. 
The incentive to conceal the skeleton in the cupboard of local republican heritage appears to present conditions for "collective amnesia" par excellence. Indeed, it has been commonly maintained that this discomfiting episode was thoroughly expurgated from social memory. If the 1798 rebellion in its entirety has been recognized as "a classic example of an Irish Lieu de Mémoire," ${ }^{4}$ it would seem that its northern arena could be labeled, to invert Pierre Nora's famous term, an Ulster lieu d'oubli. Support for the claim of total oblivion can be found, for example, in the unionist historiography that emerged in Ulster in the late nineteenth century and typically focused on events of the seventeenth century, which pitted Catholics against Protestants-namely the 1641 massacres of Protestant settlers by Catholic rebels, the 1688-89 Siege of Derry by Irish Catholic Jacobites, and the 1690 Williamite triumph over the Jacobites at the Battle of the Boyne, while neglecting $1798 .^{35}$

The historical writings of Lord Ernest Hamilton offer a prime example of this selective reconstruction of historical consciousness. ${ }^{36}$ Hamilton was a conservative MP for the Ulster constituency of North Tyrone (1885-92), who found a new vocation as a writer and popular historian. His book The Soul of Ulster (1917) was intended as an intimate history of the province and has been critically described as "schematic and selective." ${ }^{37}$ The preface notes that: "It has been very truly said that the Ulster question is only properly understood by Ulstermen, residents in other parts of Ireland having, at the best, an incomplete grasp of the real deep-down issues," to which is added that "mere residence in Ulster is not in itself sufficient to lay bare the inner soul of the people, there being in the case of the native part of the population a very wide gap between their secret feelings and that which appears on the surface." The author then goes on to establish his credentials as a knowledgeable insider, boasting that he has "had exceptional opportunities of getting occasional rather startling glimpses of the real soul of Ulster." A chapter on 1798 notes that "to the student of Irish Politics who looks below the surface, there is no episode in the history of the island more instructive, or that holds up a more minatory hand to the half-informed, than this rebellion."

None the less, the rebellion in the north is conspicuously not mentioned in Hamilton's book. Even though this was supposed to be a history of Ulster, and not of the whole of Ireland, the narrative of 1798 is confined to sectarian atrocities committed by Catholics against Protestants in the 
south. It is claimed that "these began to open the eyes of the Ulster Presbyterians to the precipice towards which they had been drifting," so that consequently "the movement was dead, as far as the Ulster Presbyterians were concerned." The misleading conclusion that "'98 and '41 were not forgotten" actually masks an attempt to promote forgetting. The bundling of the memory of 1798 together with 1641 embeds it within the familiar loyalist meta-narrative of Protestant deliverance, thus serving to obscure the involvement of Presbyterians in the rebellion. ${ }^{38}$

\section{INDELIBLE MEMORIES}

While recognizing that the airbrushing of 1798 out of Ulster history entailed a conscious effort, whereby "Ulster Protestants have sometimes engaged in a process of remembering to forget," Ian McBride perceptively suggested that it is possible to uncover traces of a "hidden history" of 1798 which persisted in the countryside, lurking in the background of a public facade of silence. ${ }^{39}$ As opposed to the more prominent works of canonical history, this is a vernacular historiography, which needs to be pieced together through inspection of less familiar, unconventional, sources rooted in local traditions. ${ }^{40}$ John Tosh likened oral tradition to a historical monograph "marked by the destruction of all copies of the previous work on the subject." ${ }^{41}$ Indeed, the historian of folklore must often make do with recordings of late versions of folk history, without direct access to earlier transmissions. Yet, remarkably, perhaps partly thanks to high literacy rates and a growing mass readership, local historical traditions were periodically documented in Ulster. ${ }^{42}$ These unique conditions enable the undertaking of what David Gross has labeled "subversive genealogy," designating an effort to chart the emergence of traditions, to follow their evolvement over time, and to identify instances when they were "re-functioned" in new contexts. ${ }^{43}$ Moreover, the constant pressures exerted by repeated attempts to suppress memories of 1798 confront such "archaeology of social memory" with the challenge of attempting a parallel "archaeology of social amnesia," in an effort to recover traces of forgetting. ${ }^{44}$

Witness accounts of 1798 were first considered by the ultra-loyalist Sir Richard Musgrave, who shortly after the rebellion began compiling sources for the writing of its history. Realizing that he had ample informa- 
tion on the south but lacked detailed knowledge of the events in Ulster, he approached local Protestant dignitaries for their recollections. Musgrave's enquiries were biased by his conservative politics, as evident in a letter he sent to George Lenox-Conyngham of Springhill, a County Londonderry magistrate and landowner: "I have been assured that the Presbyterians quitted the Papists as soon as they discovered that they were impelled by that sanguinary spirit which was ever peculiar to their religion. Any anecdotes of atrocities committed by the United Irishmen and Defenders will be very acceptable." ${ }^{45} \mathrm{He}$ discovered however that the testimonies of "suffering loyalists" did not fully comply with his predetermined conclusions, as in the reply he received from Lenox-Conyngham who confirmed "from certain information and my own observation" that there were intrareligious tensions in the rebel camp but explained that in his experience, as opposed to Musgrave's assumptions, it was the Catholics who stepped down and the Presbyterians who rebelled:

when the rebellion broke out in the county of Antrim and Derry few or none of the Papists appeared in arms. About three hundred men arose in arms in and about Maghera, but they were soon discomfited, and of all the prisoners that were taken and tried only one of them was a papist—all Presbyterians except one Church of England man. ${ }^{46}$

Undeterred, Musgrave adapted the recollections he collected to the familiar schemata established in the founding texts of loyalist collective memory of previous rebellions, namely Sir John Temple's The Irish Rebellion (1646) and William King's The State of the Protestants of Ireland under the Late King James's Government (1691), in order to present a uniform picture of Catholic rebels attempting to massacre loyal Protestants. At the same time, he also ignored information of atrocities committed by the government forces against the local population. Consequently, Musgrave's seminal history of 1798 (first published in March 1801 and soon reissued in two revised editions) - which has been labeled the "matrix of memory" for 1798 - downplayed the rebellion in Ulster, as this arena did not conform to the master narrative of atavistic anti-Protestant violence which it sought to propagate. ${ }^{47}$

The rebellion, however, left deep scars on the local population and could not simply be brushed aside and forgotten. A writer who toured County Antrim ten years later (probably the antiquarian Samuel McSkimin, 
discussed below) encountered over the course of his travels repeated references to events in 1798. On one occasion, he was deeply moved when the landlady of a public house near Lough Neagh identified rebel graves in the neighboring landscape, admitting that he had been acquainted with some of the deceased. ${ }^{48}$ Similarly, the Presbyterian physician John Gamble from Strabane, County Tyrone, who also toured Ulster around the same time, encountered evocations of 1798 throughout his journey. His travelogue, as has been pointed out by Breandán MacSuibhne, gives the impression that the north was haunted by disturbing memories of the extinguishing of United Irish radicalism, a theme he would return to address in his three-volume novel Charlton, or, Scenes in the North of Ireland, which was published in London in 1823, with a new edition issued in $1827.4^{9}$ Despite the repression in the years following the rebellion, which sought to obliterate its memory, 1798 was evidently remembered orally in intimate conversations. Moreover, folk poetry compositions of local rhyming weavers in the vernacular Ulster-Scots dialect offered a relatively safe medium for evoking the traumatic events, as evident for example in "Donegore Hill"-an acerbically penetrating description of the rebel encampment on the eve of the Battle of Antrim - by the "bard of Ballycarry" James Orr (a former United Irishman), or "The Colonel's Retreat"-a scathing depiction of the rebellion in County Down - by Francis Boyle (a conservative, who admonished his audience "no more to rebel"). ${ }^{50}$

Personal reminiscences began to appear in print, albeit guardedly, after more than two decades. The first accounts were those of Presbyterians who had not taken up arms in rebellion but had none the less been affected by it. For example, the liberal Belfast newspaper editor Henry Joy Jr. had been associated with the reformist politics of the late eighteenth century, but differed with radicals on the issue of Catholic emancipation and objected to their resorting to insurrection. He was personally acquainted with senior United Irishmen and was a cousin of Henry Joy McCracken, the leader of the rebels in Antrim, yet remained loyal to the government and supported the Union with England. When surveying the events of 1798 as part of his documentary history of Belfast published in 1817, Joy noted that he "clearly recollects the death-like silence which pervaded the streets when the counties of Down and Antrim resounded with the noise and tumult of battle" and recalled seeing how "multitudes of prisoners were brought in from the surrounding country," some of whom were 
executed. ${ }^{51}$ It was, however, apparently still too early to publish detailed recollections and his account mainly drew on newspaper sources.

In 1825, the editors of the Belfast Magazine and Literary Journal-a newly established periodical "chiefly occupied with Literary Subjects and topics of general interest connected with Life and Manner"covered that, thanks to "the kindness of out Literary Friends," they could expand the variety of articles beyond literature to include other topics of local interest, including "Scenes of the Rebellion of 1798." ${ }^{52}$ Writing under the pseudonym Iota, James Thomson-professor of mathematics at the Belfast Academical Institution (which was at the time a college dedicated to the education of Presbyterian ministers) - contributed to the first issue his recollections of the Battle of Ballynahinch. Growing up in the neighboring village of Annaghmore, County Down, he had visited the rebel camp as a child, along with other locals who had brought supplies to the insurgents, and had observed the engagement from a nearby hill. Though he had heard many stories from others, he confined his account of 1798 to his own personal reminiscences, which "retain such a freshness and strength as to seem to be stamped in indelible characters on the very substance of the mind." ${ }^{53}$ In response, Thomson's former teacher, Rev. Samuel Edgar, the Presbyterian minister in Ballynahinch, informed the editors that this account "was interesting to many of your readers."

Thomson's breaking of public silence inspired Edgar to contribute his own recollections of 1798, which he signed only with his surname initial (E). Although he harbored little sympathy for the United Irish cause, and had even tried to dissuade people in his locality from joining the rebels, Edgar maintained that "unless such particulars be recorded now, by those who had opportunities of witnessing them, they will soon be entirely forgotten. Yet they seem on many accounts to be worthy of preservation." Despite the new political climate, which discouraged mention of 1798, he argued that "recollection of troublesome periods should not be forgotten, even in times of peace and prosperity." ${ }^{54}$ Beyond reflecting the contemporary penchant for noms de plume, the choice of both authors to refrain from appending their real names to these early printed accounts (preferring pseudonyms that would have been ascertainable to local readers but less so to outsiders) suggests that they may have feared possible repercussions, or at least adverse responses, and that public discussion of the topic in the mid-1820s still required prudence. 
Literature, by assuming a seemingly harmless guise of artistic creativity, offered an outlet for addressing the memory of 1798, and publication overseas was a way of circumventing censorship. During his studies of medicine in Scotland, the author James McHenry from Larne, County Antrim, composed a poetical description of the rebellion titled "Patrick," which portrayed graphic descriptions of the devastation that he had witnessed as a thirteen-year-old child. Upon publication in 1810, the poem enjoyed instant popularity, selling over seven hundred copies in less than a month. ${ }^{55}$ In 1824, writing from the safety of America and using the pen-name Solomon Secondsight, McHenry depicted the rebellion in his historical novel The Insurgent Chief; or, the Pikemen of'98. This pioneering contribution to establishing a cultural memory of 1798 enjoyed considerable popularity and was soon reprinted in London and later reissued in Dublin (1838). It aroused particular curiosity in Ulster and was eventually published there in an enhanced edition (1844) for which the author (who had since returned home as a U.S. consul) acquiesced to entreaties of the Belfast publisher John Henderson and added an appendix that commented on the historical accurateness of the novel's narrative and the portrayal of its protagonists. ${ }^{56}$ An initiative to perform a dramatized version in Belfast was considered too sensitive, as some of the real-life characters were still alive, and was canceled following the intervention of a magistrate. ${ }^{57}$

Rev. William Hamilton Maxwell, an Anglican clergyman posted in the West of Ireland, who aspired to be a popular writer, cut his teeth with the novel O'Hara; or, 1798, a romanticized tale of an Ulster Protestant landlord who cast his lot with the rebels. Raised in Ulster, Maxwell had been affected by the rebellion in his childhood, having witnessed at the age of eight the hanging of two United Irishmen in Newry, on the border of Counties Down and Armagh. Though he was a professed loyalist and would later write a history of 1798 that was deprecatory of the United Irishmen, the novel empathizes with the cause of Presbyterian radicalism and is sympathetic in its depiction of Ulster rebels, while showing disdain for the unfolding of the rebellion in the south. It was published anonymously in London, but proved to be unsuccessful, and Maxwell would gain a literary reputation only with his Stories of Waterloo (1829), which addressed the more patriotic and less controversial topic of the Napoleonic wars. ${ }^{58}$ 
The author and historian Eyre Evans Crowe published anonymously The Northerners of 1798 (1829) in a volume dedicated to "Ireland's Warmest Friend," the Marquis of Lansdowne, Lord Henry Petty—an influential Whig politician who at the time of writing was home secretary. Unlike McHenry and Maxwell, who had childhood memories of 1798, Crowe was born in Southampton shortly after the rebellion and, though raised and educated in Ireland, he did not reside in Ulster. His historical novel used the setting of the rebellion in the north to denounce the excesses of Orangemen and criticize the practices of the Anglo-Irish ascendancy class lording over Ireland by presenting "tales, illustrative of her political state." ${ }^{59}$ It was published by the London publisher Henry Colburn, who in the late 1820s identified a growing market in Britain for historical and fictional accounts of 1798. After publishing Wolfe Tone's memoirs (1827), Colburn published the Personal Narrative of the northern United Irishman Charles Hamilton Teeling (1828), which was soon supplemented by a sequel published in Belfast (1832).

Teeling came from a family of Catholic linen merchants in Lisburn (near the boundary of Antrim and Down), which was well connected with Presbyterians in the locality. He was associated with the upper echelons of the United Irishmen and in $\mathbf{1 7 9 8}$ his elder brother Bartholomew was executed for taking part in the French invasion of the West of Ireland. At the time, in an attempt to play down his own involvement, Charles Hamilton wrote the Lord Lieutenant to say "I neither acted nor aided in the late rebellion." ${ }^{60}$ Yet the account which he wrote three decades later was peppered with personal recollections, recounting his experiences in escaping the repression after the defeat of the rebels. He attributed central significance to the insurrection in Ulster and dwelt on the government's "Reign of Terror," detailing excesses committed by troops against civilians. By giving vent to local experiences of the rebellion in the north, Teeling forcefully posited a counter-memory against the selective forgetting instigated by Musgrave, and his narrative would be consulted as a primary source by subsequent writers. ${ }^{61}$ 


\section{COLLECTING LIVING MEMORIES}

Fieldworkers of the Ordnance Survey, who visited the area in the 1830s, documented local traditions in memoirs, which were intended as supplements for topographical maps. They encountered communities that "were almost to a man implicated in the rebellion of 1798 , but the examples made of them by hanging gave them a distaste for such proceedings and has since had a salutary effect on them, besides effecting a total change in their political sentiments." ${ }^{62}$ From passing references scattered throughout the memoirs, it is apparent that memories of 1798 were part and parcel of the vernacular cultural landscape, but, as the memoirists were perceived as representatives of the government partaking in a military project, locals responded cautiously and refused, for example, to divulge the whereabouts of hiding places used in $1798 .^{63}$ The veil of silence was penetrated only by exceptional surveyors, such as the Gaelic scholar John O'Donovan, who earned the confidence of some residents and was introduced to members of respected families that had participated in the rebellion. ${ }^{64}$

Around that time, Samuel McSkimin — a Presbyterian antiquarian and shopkeeper resident in Carrickfergus, County Antrim, who was credited by Ordnance Survey memoir writers in his area for having assisted them-was preoccupied with revising a local history he had published thirteen years after the rebellion. Though purporting to cover events up "to the present time," the original edition elided 1798 in an attempt to shroud the memory of recent Presbyterian radicalism and violent strife. The Presbyterians of Ulster were described as "generally peaceable and industrious" so that "perhaps in no place of this kingdom do fewer breaches of the public peace take place," and "between the members of the different religious sects, the utmost harmony always prevails." Misleadingly asserting that "no where in this kingdom are religious or political distinctions less known," McSkimin claimed that "in 1798 and some years preceding, when party distinctions ran high in most places, fewer excesses were committed within this district than, perhaps, in any other place in Ireland." ${ }^{65}$

Memories of 1798, however, loomed heavy on McSkimin, a loyalist who had been forced to leave his home in Ballyclare in 1797, possibly in consequence of having informed on United Irishmen, and who had taken up arms against the rebels as a yeoman. ${ }^{66}$ An enhanced edition of his book came out in 1823 , to be followed with further revisions in 1829,1833 
and 1839, for which he "studiously engaged in collecting materials," and these all included entries on the rebellion. ${ }^{67}$ His historical narrative was primarily addressed to a conservative readership and made no secret of the author's antipathy to the United Irishmen. Yet, despite his preference for Orange sources, McSkimin was captivated by recollections of former rebels and went around the countryside plying common people with drink, at considerable personal expense, in order to cajole them into talking about $1798 .{ }^{68} \mathrm{He}$ ended up writing an extensive history of the rebellion in Ulster, which was published posthumously. ${ }^{69}$

In contrast to McSkimin's hostile prejudice, Richard Robert Madden, a Catholic doctor from Dublin and former colonial administrator, who was also a prolific writer, became impassioned with rewriting the history of 1798 from an appreciative point of view. His tireless efforts to track down surviving former rebels and their relatives brought him in contact with a radical coterie of diehard northern radicals centered on the household of Mary Ann McCracken, sister of the United Irish leader Henry Joy McCracken, who was executed in Belfast in 1798. Over a period of twenty years (1840-59), Madden corresponded with the venerable McCracken, from when she was aged seventy to ninety, and she introduced him to other knowledgeable persons. ${ }^{70}$ Among them was the linen weaver and veteran rebel James (Jemmy) Hope, whom Madden first met in 1843. By encouraging the eighty-year-old Hope to write his remarkable autobiography and publishing it, Madden salvaged the account of a hitherto unrecognized plebeian insurgent from oblivion and afforded him lasting public acclaim as a working-class hero.

Even though Mary Ann McCracken had reconciled herself over the years with the United Kingdom-maintaining that "Ireland would have a better chance of justice when the liberals of both countries were united in one parliament, than when divided," she and her colleagues remained aloof from local unionist conservatism and championed radical political causes, in particular abolitionism (a cause shared by Madden, who had overseen emancipation of slaves in several colonial postings). Above all, they saw themselves as faithful guardians of the memory of the United Irishmen and felt betrayed by McSkimin, whose papers they had hoped to get hold of and edit, in an attempt to instigate "counter-forgetting," so "that truth and falsehood might be separated while there were living witnesses competent to do so."71 Once Madden gained their confidence, 
he became privy to a wealth of oral history and tradition, much of which had been preserved by women-sisters, wives, lovers and daughters of dead United Irishmen.

These "subaltern" recollections would be incorporated into Madden's monumental The United Irishmen: Their Lives and Times (originally issued in seven volumes between 1842 and 1846, followed by the publication of four additional volumes between 1857 and 1860), which became the canonical text of nationalist counter-memory. ${ }^{72}$ Though this multiplevolume history was soon out of print and became a rare collector's item, the biographies of prominent northern United Irishmen were later reissued in a separate, more affordable, volume. ${ }^{73}$ Thanks to Madden, underground memories of the rebellion, which till then could not have been committed to print, entered the public domain, offering a counterweight to Musgrave's omissions and the pressures exerted in favor of forgetting 1798.

Rev. Classon Porter, the Presbyterian minister in Larne and historian of the Kilwaughter congregation, also attributed great value to memories of elderly people. ${ }^{74}$ Being a relative of Rev. James Porter-a radical Presbyterian minister and United Irishman, who in 1798 was publically executed in front of his congregation at Greyabbey, County Down-Classon Porter was fascinated with the rebellion. Starting in the 1840s and resuming his work in the early 1860s, he too diligently collected stories and songs from "survivors of that time and elsewhere," such as the ninety-one-year-old James Burns-nicknamed "the Old Croppy" (Croppy being a common nickname for rebels in 1798), whom he interviewed over several meetings in $1863 .^{75}$ In this way, the recollections of rebels were documented from different perspectives - by a political opponent (McSkimin), a sympathetic outsider (Madden) and an interested local (Porter) - and, though each of them worked independently, collectively their efforts checked the drive towards forgetting.

Beyond literary representations and oral recollections, a carefully preserved material culture of privately cherished aide-mémoires also played a role in defiantly maintaining the memory of 1798 in Ulster. In September 1852, to mark the convening of the British Association for the Advancement of Science in Belfast, a "collection of antiquities and other objects illustrative of Irish history" was put on display at the Belfast Museum. Residents from throughout the province donated an array of artifacts, which reputedly "excited the astonishment of visitors by the number and 
variety of these relics." Among them could be found several items from the time of the rebellion, including iron pike heads used by insurgents, a ribbon worn by a rebel at an engagement in Randalstown, County Antrim, and a commemorative medallion minted in memory of the United Irish Presbyterian martyr William Orr. Despite the public transition in political persuasion, people in unionist areas were devotedly holding on to mementoes from the time of the rebellion and, when put on display, these items aroused wider local interest. Noting the overwhelming success of the event, the organizers commented that it "will long be remembered by those who have had an opportunity of visiting it." 76

In face of increasing consolidation of unionism throughout Protestant Ulster in the second half of the nineteenth century, local travel literature reveals continued interest in 1798 within communities that had been formerly rebellious. In 1857, when the Ballymena Observer published "Walks about Ballymena" in what by then had become a zealously loyalist area, "the memorable year of 1798 " featured prominently. Although the editors professed that they had no intention of "writing a history of the insurrection," they soon realized that they had unwittingly "much exceeded the space originally intended for occupation by this subject." Enthrallment with the rebellion was apparent, regardless of reference to executed rebels as "deluded victims of an epidemical insanity," who had been involved in "criminal proceedings." 77

Similarly, a Guide to Belfast, the Giant's Causeway and the Adjoining Districts of the Counties of Antrim and Down from 1861 included a previously unpublished account of the battle of Ballynahinch, alongside numerous references to 1798 . The author-the journalist and poet William McComb, who would later be described as "the Laureate of the [Presbyterian] Church"-was a committed unionist. As a young apprentice draper in early-nineteenth-century Belfast, he founded a Sunday school which sought to counteract any lingering remnants of Painite ideas and in the early 1840s he celebrated loyalist Belfast's opposition to the nationalist leader Daniel O'Connell. He considered the 1798 rebellion "a melancholy exhibition of folly and recklessness," claiming that "intelligent Irishmen now wonder how their fathers could have been so befooled as to think of a separation from England" and "grandmothers may entertain children in the nursery with stories of ' 98 , but we trust that there will never be a repetition of the scenes of that awful year." Yet, he diligently poured 
over historical sources concerning the rebellion, collected local traditions and even composed a poem about the rebel folk heroine Betsy Gray. ${ }^{78}$ Despite political pressure in the present to forget and move on, people were compelled to remember the painful past.

\section{RECOVERING MEMORY}

With the passing away of the generation that had experienced the traumatic rebellion, the vividness of personal recollections seemed to succumb to forgetfulness. In 1877, the Belfast historian George Benn observed that "to the present generation the entire [history of 1798 in the north] is almost an unknown story - 'a tale of the times of old." Northeast Ulster, more than any other place in Ireland, was influenced by the modernizing impact of industrialization and in the new political and economic context the circumstances of the late eighteenth century seemed increasingly irrelevant. In Benn's opinion, “the majority in this young, busy, commercial community" no longer showed interest in "the eloquent and passionate appeals" of the United Irishmen. ${ }^{79}$ None the less, local interest persevered and, as demonstrated by the literary efforts of talented individuals, evergrowing remoteness could be bridged by imaginative cultural production. Born more than a quarter century after the rebellion, the physician and businessman Thomas Charles Steuart Corry was captivated with the United Irishmen. Choosing to ignore the risk that dwelling on this touchy subject might alienate loyalists and harm his many successful commercial initiatives, he wrote a long poetic composition on the Battle of Antrim, which masqueraded as a personal reminiscence of an aging rebel, though presumably by then none of them were still alive. Originally published as a booklet (1875), it was reproduced as the opening of a collection of Corry's poems, which was "respectfully dedicated" to Madden by "his sincere admirer" and also included an "Ode to the Memory of Mary Ann McCracken." $" 80$

The extent to which fascination with 1798 persisted was revealed by the phenomenal popularity of a historical novel by the journalist Wesley Greenhill Lyttle-Betsy Gray or, Hearts of Down: A Tale of '98, which became a local bestseller. Lyttle, a former schoolteacher who had been a lecturer in Corry's "Irish Diorama" traveling pictorial heritage show (lauded 
by the Ulster Observer as "the most popular entertainment ever given in Belfast") ${ }^{81}$ initially serialized the novel in his liberal newspaper the North Down Herald and Bangor Gazette (beginning on November 7, 1885). It drew extensively on folklore traditions, which Lyttle had encountered growing up in Newtownards, County Down, and had later collected around Six-Road-Ends, an area associated with the 1798 folk heroine Betsy Gray. These vernacular accounts were restyled in romantic prose and adapted to a melodramatic narrative, while maintaining much of the local UlsterScots dialect. First published as a book in 1888, it would be reissued in numerous editions to the effect that, as noted by Aiken McClelland of the Ulster Folk Museum, "for many years after its first publication, this was a standard book in almost every County Down home." ${ }^{82}$ Other contemporary historical novels set in Antrim and Down during the 1798 rebellion were published in London with a broad readership in mind, including Hester's History (1869) by the Belfast-born author Rosa Mulholland (later known as Lady Gilbert); Strong as Death (1875) by County Down author Mrs. Charles Montague [Marion] Clarke, who claimed that the book was largely drawn from "traditional lore" that she had heard from her mother; and Peggy (1887) by Mary Damant, who drew upon stories she had heard in childhood from "those whose recollection of the rising was rendered vivid by desolate homes, and by the loss of relations who had fallen in the field, or found a more dishonourable fate" (in his boyhood, her father-Francis Rawdon Chesney of Annalong in County Down-had assisted his father in opposing the rebels in 1798) ${ }^{83}$ In contrast, Lyttle's novel was primarily intended for a local audience, though its remarkable success attracted readers from afar, including William Gladstone ${ }^{84}$ Clearly, preoccupation with the memory of the 1798 rebellion in Ulster refused to pass away, in spite of the accelerated growth of unionism.

Towards the end of the nineteenth century, a concerted effort was made by antiquarians in Ulster, who were by and large Protestants, to salvage living memory. ${ }^{85}$ Concerned that "the face of the country is changing, and local sources of information gradually dying out" and reluctant "to allow records and investigations into the past history and antiquities of our Province to pass into oblivion," they revived the Ulster Journal of Archaeology, specifically undertaking to allocate space "to the Insurrection of '98." 86 The journal's editor, the polymath Francis Joseph Bigger, one of Ulster's more colorful characters at the fin de siècle, had developed 
an obsession with 1798 when as a child he was sent for health reasons to the countryside in Carnmoney, County Antrim and had first heard there stories of the rebellion. ${ }^{87}$ Bigger saw himself following in the footsteps of Madden:

It has fallen to me, brought up in the country of the northern leaders of the insurrection of ' 98 , related to several of them, familiar with their homes and haunts, acquainted with the scenes of their deaths, a frequent visitor to their graves, their people and my people known and connected with each other, their names household words-it has fallen to me to be a chronicler of their lives and actions. ${ }^{88}$

The journal's coeditor, Robert Magill Young, published a collection of historical traditions titled Ulster in '98: Episodes and Anecdotes, observing: "the social and local details of the struggle in Ulster are dying fast out with their narrators. It is with the hope of preserving some material of this description, however scanty, that the present little work has been attempted." 89

Another contributor to the journal, Rev. William Sunderland Smiththe minister of the non-subscribing Presbyterian congregation in Antrim town-also compiled a collection of Memories of '98, noting:

Many of the events of a minor character, hitherto unrecorded, connected with the Insurrection of 1798, are fast becoming the merest traditions. Those who personally took part in them, or were in any way concerned with them and were well acquainted with their details, have all passed away. Only the children of such, or the grand children, or still more distant relatives, now survive to hand on, too often with strange indifference, the facts still remembered of what at first may have been incidents of such interest. ${ }^{90}$

In addition, the Presbyterian minister and historian Rev. William Thomas Latimer published in local newspapers biographies of prominent Ulster rebels, making use also of oral traditions, which he then compiled into a book. ${ }^{91}$

In 1895, Bigger sponsored the foundation of a Henry Joy McCracken Literary Society, which published a short-lived journal the Northern Patriot. It was succeeded by the Shan Van Vocht, edited by two radical Protestant women, Alice Milligan and Ethna Carbery (pen-name of Anna Johnston). 
Over three years (1896-99), this militant nationalist journal openly solicited and published traditions of 1798 , alongside original writings relating to the rebellion. In some cases, new compositions would prove to be more memorable than genuine historical traditions, as in a poem Carbery wrote about an Antrim rebel named Rody MacCorley, which would enjoy popular success when sung as a ballad, whereas a long-forgotten poem from around the time of the rebellion, which may have been its source of inspiration, fell into obscurity. ${ }^{92}$ This cultural flourish celebrating the memory of 1798 marked the commencement of preparations in Belfast for the centennial commemorations. ${ }^{93}$ In 1898, the novel The Green Cockade: A Tale of Ulster in 'Ninety-Eight by Margaret Teresa Pender, who was born in Ballytweedy, County Antrim, of a mixed marriage between a Catholic farmer and Presbyterian woman, enjoyed popularity amongst nationalists. ${ }^{94}$

\section{CONFliCTED MEMORIES}

When considered in its entirety, the vernacular historiography spanning the nineteenth century reviewed above demonstrates that in practice 1798 was not simply cast aside. At the same time, detailed inspection of the sources reveals that this was not a straightforward case of tenacious persistence of counter-memory, which could self-assuredly ignore hegemonic calls for forgetting. The "underground" memory of 1798 was inherently riddled with ambiguities. Over the years, the collectors who had undertaken the documentation of recollections came from different ideological persuasions, including conservatives, liberals and radicals, and their conflicting politics encouraged diverging attitudes to the rebellion. Similarly, the narrators who were interviewed included both supporters and opponents of the rebellion and in some cases their relationship to historical personages was mixed. For example, a key informant of the antiquarian W. S. Smith-Mrs. Graham Shannon of Antrim-was the daughter of a yeoman who had fought against the rebels and lived to the age of eighty-two, while her maternal grandfather was Robert Lennon, the leader of a rebel contingent from Ballynure. ${ }^{95}$ Those who regretted, or even deplored, the rebellion could still express admiration for the ideals that the rebels championed. For example, the liberal Presbyterian minister Rev. Henry Montgomery of Killead, County Antrim, who had traumatic recollections of 1798-when 
as a boy of ten his house was burnt down by yeomen and his two rebel brothers were imprisoned-wrote some fifty years later:

It cannot, however, be denied that principles, sound in themselves, and whose enunciation would produce no injurious effect upon enlightened minds, may be brought so to bear upon the multitude as to result in consequences the most disastrous. So it was, unhappily, with the principles of the Society of United Irishmen. Young men, weak men, enthusiastic men, and, above all, wicked men, so misapplied and perverted them, as to delude the unwary, to involve thousands in criminal projects under false notions of patriotism; and, finally, to crimson the green fields of our country with the blood of her children. ${ }^{96}$

It appears that among those looking back at Ninety-Eight, censure was often tinged with empathy, just as reverence was tainted by regret.

Moreover, the narratives present an intricate picture, which juxtaposes unconventional stories of forced recruitment by rebels with tales of involuntary conscription by yeomen; accounts of United Irishmen who forsook the rebel army and even turned into loyalists are found alongside cases of loyalists who furtively assisted rebels; gruesome descriptions of excesses committed by the Crown forces are counterbalanced by atrocities perpetrated by rebels. Such nuanced complexity, which dwelt on the civil war aspects of 1798, precluded the smugness often generated by simplistic narratives of righteous rebels resisting tyrannical soldiers, typically found in folk remembrance of rebellion. The characteristic ambiguity is encapsulated in the name given to the rebellion in popular parlance- "the Turn Out," as noted by McSkimin (and confirmed by others): "In speaking of this insurrection it is very rarely called a rebellion, but commonly the "turn out; the call used at the time, to those who appeared tardy to come forth to the ranks." 97 This was a fragile memory, its confidence perforated by the desire to forget, or at least cover up, lingering self-doubts.

A century after the rebellion it seemed that the memory of 1798 could finally come out of the closet. For Irish nationalists, who desired the abolishment of the Union with England, 1898 offered an opportunity to symbolically proclaim the rise of a counter-hegemony, which audaciously challenged the dominance of British imperial hegemony and its monopoly of commemoration in the public sphere. Accordingly, the centenary of 
1798 was staged as a nationalist counter-demonstration to the loyalist celebrations of Queen Victoria's diamond jubilee the previous year. With all nationalist movements wishing to gain cultural capital from the commemorations, centennial organization suffered from internal rivalries. The dominant coordinator of commemorations in Ulster was Joseph Devlin, a dynamic Catholic nationalist supporter of the John Dillon faction in the Irish Parliamentary Party. ${ }^{98}$ His directives were contested by the more radical separatist nationalists of the Irish Republican Brotherhood (IRB), who considered themselves the rightful heirs of the United Irishmen and took offence from constitutionalists commemorating republican rebels. ${ }^{99}$ In addition, the Catholic Church promulgated a "Faith and Fatherland" reinterpretation of 1798, formulated by the Franciscan historian Fr. Patrick Kavanagh, which ironically mirrored the loyalist interpretation of a sectarian insurrection and therefore preferred to ignore the specificities of the rebellion in Ulster. ${ }^{100}$ Though the many centennial '98 clubs established in Ulster were typically named after Presbyterian United Irish heroes, most of the membership was Catholic, apart from a handful of maverick Protestant supporters of Irish nationalism. This composition did not sit well with the majority Protestant population in the region.

By the time of the centenary, sectarian polarization in Ulster had stiffened. The evangelical revival of the mid-century (which peaked in 1859) brought Presbyterians closer to other Protestant groups and posited them against Catholics. ${ }^{101}$ Orangeism reappeared as a popular grassroots movement in response to the nationalist agrarian agitation of the Land War (c. 1879-81) and unionism became far more militant and rooted in northeast Ulster through resistance to the Home Rule Bill initiatives of 1886 and 1893, drawing together Presbyterians and Church of Ireland Protestants in opposition to Catholic nationalists. ${ }^{102}$ Whereas the persistence in the private sphere of an ambivalent affinity to 1798 could be tolerated, the co-option of its memory in public by Catholic nationalists was considered an anathema.

When loyalists contemplated organizing a counter-demonstration to face the nationalist commemoration in Belfast, the Grand Orange Lodge of Belfast passed a unanimous resolution "That it would be entirely contrary to the principles of the Loyal Orange Institution to interfere with any section of our fellow-citizens in celebrating whatever event in their history commends itself to their good taste and deliberate judgement as deserving 
of public commemoration and honour." While stating that he considered commemoration of 1798 "a flagitious display of sympathy with an armed insurrection, which above all things, was characterized by a series of most foul and cowardly murder and massacres of innocent men and women, whose only offense was their Protestantism," the Grand Master Rev. Kane issued a call that "All the loyal inhabitants will show so much respect for their principles, for their dignity, and the good name and interests of the city as to abstain from any interference whatever with the demonstrators, leaving them to bring that contempt upon the procession which they are quite capable of doing themselves." ${ }^{103}$ In reality, however, this plea for toleration was not adhered to.

The commemorative procession in the Catholic area of Hannastown on June 6 ignited riots on the unionist Shankill Road, which spread throughout the city and continued for several days, necessitating large deployments of military to restore order. The following month, the Orange commemorations of July 12 , which were staged that year as a loyalist triumphalist riposte to nationalist celebrations of 1798, provoked rioting in Catholic neighborhoods. A month later, when northern nationalists participated in the central commemoration of 1798 in Dublin (August 15), their trains were attacked upon returning to Belfast and once again riots broke out. Through such spontaneous outbursts of violence, Protestant loyalists expressed their abhorrence of the centennial commemorations. The desire to obliterate the memory of 1798 was particularly noticeable on May 1, when a party of nationalists visiting the recently erected memorial to Betsy Gray in the staunchly unionist area of Ballynahinch was assailed by loyalists, who then destroyed the monument. ${ }^{104}$ These acts seem to signify that Ulster Protestants had finally released themselves from the burden of remembering 1798. However, even this purge did not result in extinction of memory. Studies of such political attacks on memory in ancient Rome have revealed that what scholars have labeled damnatio memoriae "was not exactly about the destruction of memory, though ancient sources insist that it was" and "what actually occurred was a highly symbolic, universal display of pantomime forgetfulness." ${ }^{105}$ Consequently, "damnatio memoriae did not negate historical traces, but created gestures which served to dishonour the record of the person and so, in an oblique way, to confirm memory." 106 
The memory of 1798 indeed refused to fade away in the twentieth century. The centennial enjoyed a long afterlife in cultural production. The antiquarian circle around Bigger continued to publish material on United Irishmen over the next decade. ${ }^{107}$ Several additional novels on the Rebellion in Ulster appeared and were favorably received. These included The Pikemen (1903) by the Antrim politician and novelist Sir Samuel Robert Keightley, which was reissued in four editions by 1906; A Prisoner of His Word (1908) by the Dublin suffragette Louisa (Louie) Bennett; The Northern Iron (1907) by the Belfast-born novelist George A. Birmingham (pseudonym of the Church of Ireland clergyman Rev. James Owen Hannay) - a critically acclaimed book, which went through several editions and numerous printings; and the collection of interlocking short stories Ninety-Eight and Sixty Years After (1911) by Andrew James (pseudonym of James Andrew Strahan, Professor of Jurisprudence and Roman Law at Queen's University Belfast), whose grandfather had been among the rebels in 1798. ${ }^{108}$ Two melodramatic plays about 1798 in the north by the popular Dublin dramatist Patrick John Burke were presented to southern nationalist audiences-The Northern Insurgents Ulster in 1798 (1912), staged at the Queen's Theatre, and For the Land She Loved (1915), performed at the Abbey Theatre in Dublin. ${ }^{109}$ There is even some documented evidence that certain unionist families continued to recount traditions of the rebellion in private settings. For example, in his autobiography, Baron John Clarke McDermott-Lord Chief Justice of Northern Ireland from 1951 to 1971-recalled how his father-Rev. John MacDermott, Presbyterian minister of Belmont and moderator of the Presbyterian Church in Ireland-had told him in his childhood "the sad story" of the execution in 1798 of the radical Presbyterian minister Rev. James Porter on charges that fell "far short of treason in my Father's view." $" 110$

However the political situation would change dramatically following the partition of Ireland in 1921 and the foundation of Northern Ireland as an autonomous unionist state within the United Kingdom, which privileged Orange culture and showed little tolerance for alternative traditions. The Northern Irish authorities considered republicanism an internal threat and prohibited, or at least did their best to curtail, public commemoration of the United Irishmen. Yet even when backed by all the capabilities of a modern state, armed with enhanced security enforcement 
and empowered by emergency legislation, concerted efforts to enforce an official ban did not result in total forgetting. Oral traditions continued to be transmitted. Michael J. Murphy, a collector of the Irish Folklore Commission who undertook considerable fieldwork in Ulster, encountered in the 1950s stories pertaining to $1798 .{ }^{111}$ Similarly, a more limited folklore collecting initiative run by the Committee on Ulster Folklife and Traditions in the 1950s also received a number of accounts of 1798 from Antrim and Down. ${ }^{112}$ When the County Down newspaper the Mourne Observer serialized Lyttle's classic Betsy Gray in 1967-68, it was met with tremendous enthusiasm and an outpour of readers' letters reveals that local Presbyterians were faithfully holding on to family traditions. ${ }^{113}$

Reflecting on contemporary history of political silencing, Jay Winter has drawn attention to the role of writers and artists, who "occupy liminal positions within society, and sometimes manage to say the unsayable" by exercising poetic license. ${ }^{114}$ Several Northern Irish authors maintained a fascination with the United Irishmen. The Presbyterian working-class writer Thomas Carnduff, even though he was a member of the Ulster Special Constabulary, gave public talks on the topic of 1798 and made it the setting for his historical drama Castlereagh, which was first performed at Belfast's Empire Theatre in 1935. ${ }^{115}$ The Catholic raconteur Cathal O'Byrne, who as a young man had been an associate of the cultural in-group surrounding Bigger around the time of the centennial, recycled many anecdotes and stories of 1798 in his popular articles on local Belfast history and folklore that appeared in the nationalist newspaper the Irish News from the late 1930s and were subsequently collated into a popular book, which went through two editions and several reprints. ${ }^{116}$ The Group Theatre produced in 1945 Jack Loudan's play Henry Joy McCracken about the last days and execution of the 1798 hero. ${ }^{117}$ In 1948, legal prohibitions were relaxed in order to permit limited commemoration of 1798. After the anxious government took measures to "prevent disorder arising from the processions and meetings," 118 nationalists in Belfast celebrated the sesquicentenary in a series of public events, much to the chagrin of unionists. ${ }^{119}$

During the years of the Troubles - the violent sectarian civil strife that raged in Northern Ireland from the late 1960s to the late 1990s- the United Irishmen was hailed in pamphlets, songs and murals by militant republicans and this politicized subculture was reviled by unionists. At the same time, memory of 1798 was evoked in mainstream culture in 
the works of several exceptional writers, including the poetry of Seamus Heaney, ${ }^{120}$ Sam Hanna Bell's novel A Man Flourishing (1973), ${ }^{121}$ Stewart Parker's play The Northern Star (1984), ${ }^{122}$ John Hewitt's radio play, The McCrackens, ${ }^{123}$ and Gary Mitchell, Tearing the Loom (1998). ${ }^{124}$ Following the de-escalation of violence marked by paramilitary cease-fires, the bicentennial of 1798, which coincided with the signing of the Good Friday Agreement (1998), occurred at a period of calm and opportunity, which promised to put an end to the Northern Irish conflict. Reconciliation, with its associations of forgiving and recognizing the traumas of others, tends to open new spaces for commemoration, which can transcend amnesties on painful memory imposed by dominant groups. ${ }^{125}$ In this new optimistic atmosphere, 1798 was commemorated openly by communities throughout Ulster, allowing many individuals to discover a newfound pride in a long-suppressed heritage. ${ }^{126}$

\section{SOCIAL FORGETTING AND THE MEMORY BOOM}

Overall, it may appear from this historical survey that the case of 1798 in Ulster is more a story of remembering than forgetting, but to reach such a hasty conclusion would miss the point. Recent psychological studies have moved away from conceptualizations of forgetting in opposition to memory and concluded that "the study of forgetting cannot be separated from the study of memory." 127 Contesting the standard reference to forgetting "in the context of dysfunctions of mnestic [i.e. relating to memory] operations, along the uncertain border between the normal and the pathological," the philosopher Paul Ricoeur suggested the "paradoxical idea that forgetting can be so closely tied to memory that it can be considered one of the conditions for it," putting forward a compelling concept of "imbrication of forgetting in memory." 128 Similarly, social forgetting is inextricably tied in with social remembering. Whereas the notion of silence has been proposed as a space in between memory and forgetting, ${ }^{129}$ a deeper probing of what could be perceived as socially constructed silence can reveal that it may actually mask considerable expressions of remembrance. Social forgetting in this sense pivots on tensions between public calls for silence and demands for recognition of private recollections. Unlike hegemonic attempts to create an official sanitized collective memory, in order to promote a comfort- 
able image of the past, social forgetting thrives on contestation (or, to use Ricoeur's terminology, "dissensus"). It is the outcome of compulsive engagement with a relentlessly disturbing past and its inherent ambiguity assists in sustaining, rather than eliminating, social memory.

Contrary to the prospect of increased forgetting with the passage of time in accordance with Hermann Ebbinghaus's famous "memory curve," which is still employed in psychological studies of forgetting, ${ }^{130}$ the abundance in 1998 of celebratory memorials, pageants, performances, exhibitions, conferences, lectures, publications and television programs, which all received official endorsement, reflects the removal of inhibitions and suggests the ultimate overturning of social forgetting. To use terms introduced by Graham Dawson in his study of memory and trauma of the Troubles, the bicentennial commemorations could be construed as a mass exercise of "reparative remembering," which "is not entirely a matter of draining the poison of the past but also involves deepening, making more complex and enriching a living relationship with it." ${ }^{131}$ The outpour of this mnemonic torrent, with its inlets into traditional local reservoirs of folk memories, casts doubts on the universal applicability of the sociological claim that modernity (or perhaps postmodernity) inevitably ushers in corrosive forgetting. ${ }^{132}$

However, upon reflecting on the startling success of the commemorations, the historian A. T. Q. Stewart perceptively observed that they still maintained a degree of ambivalence. Following the publication of The Summer Soldiers (1995) - his comprehensive study of the rising in Antrim and Down, a work that he had been contemplating for the previous thirty years-he "received many letters from people whose ancestors had been out in 1798. None was hostile, and all were seeking more information." Amid this explosion of interest, he noted that some people were baffled by the bicentennial of the rebellion in Ulster: "the fact that Presbyterians actually looked back on it with pride was confusing. Add to this that some Orangemen believed that what they were commemorating was the putting down of the Rebellion." He also acknowledged that "there are, of course, some in both communities in the North who, for different reasons, viewed the extent of Presbyterian involvement with some embarrassment." 133 Behind the extravaganza of the memory boom, which had finally overtaken Ulster, traces of a long history of disremembering were still faintly apparent. 


\section{NOTES}

The research for this article was initially sponsored by the Irish Research Council for the Humanities and Social Sciences, followed by a grant by the Israel Science Foundation (grant no. 810/07), and has also benefited from a NEH fellowship at the Keough-Naughton Institute of Irish Studies in the University of Notre Dame. It takes its inspiration from the pioneering work of the late A. T. Q. Stewart and of Ian McBride.

1. Belfast News-Letter, May 21, 1898.

2. Lurgan Mail, April 2, 1898; Rev. R. S. O'Loughlin, The Rising of '98 (Lurgan: L. Richardson, 1898).

3. Belfast News-Letter, May 10, 1898.

4. Ibid., June 11, 1898. The capitalization of “Turn Down” may signify a subtle reference to the popular name of the 1798 Rebellion in Ulster, which was commonly known as the "Turn Out" (see p. 30 below).

5. Belfast News-Letter, May 21, 1898. For a survey of attitudes to the 1798 centenary in the unionist press, see Marc Mulholland, "Not a Historical but a Prospective Application'? The 1798 Rising as Recalled in the Irish Popular Press of 1898," in David George Boyce and Alan O'Day, eds., The Ulster Crisis, 1885-1921 (Basingstoke and New York: Palgrave Macmillan, 2006), 165-81 (esp. 174-81).

6. See Stuart Andrews, Irish Rebellion: Protestant Polemic, 1798-1900 (Basingstoke and New York: Palgrave Macmillian, 2006).

7. See James Kelly, “'We Were All to Have Been Massacred': Irish Protestants and the Experience of Rebellion," in Thomas Bartlett, David Dickson, Dáire Keogh and Kevin Whelan, eds., 1798: A Bicentenary Perspective (Dublin: Four Courts Press, 2003), 312-30 (esp. 313-16).

8. For collaboration and antagonism between Catholics and Presbyterian rebels, see Marianne Elliott, The Catholics of Ulster: A History (London: Allen Lane, 2000), 248-59.

9. For an overview of the functions of memory in relation to Irish communalsectarian identities, see Ian McBride, "Memory and National Identity in Modern Ireland," in Ian McBride, ed., History and Memory in Modern Ireland (Cambridge and New York: Cambridge University Press, 2001), 1-41.

10. See Jonathan M. Golding and Colin M. MacLeod, eds., Intentional Forgetting: Interdisciplinary Approaches (Mahwah, NJ: Lawrence Erlbaum Associates, 1998), esp. Colin M. McLeod, "Directed Forgetting," 1-57.

11. Eviatar Zerubavel, The Elephant in the Room: Silence and Denial in Everyday Life (Oxford and New York: Oxford University Press, 2006), esp. chap. 7: "The Trouble with Elephants," 79-87. 
12. "The Germans," Fawlty Towers (BBC, 1975), series 1, episode 6; see John Cleese and Connie Booth, The Complete Fawlty Towers(London: Methuen, 1988), 135-57.

13. See Ian McBride, Scripture Politics: Ulster Presbyterians and Irish Radicalism in Late Eighteenth-Century Ireland (Oxford: Clarendon Press, 1998); also idem, “'When Ulster Joined Ireland': Anti-Popery, Presbyterian Radicalism and Irish Republicanism in the 1790s," Past and Present 157, no. 1 (1997): 63-93.

14. William Theobald Wolfe Tone, ed., Life of Theobald Wolfe Tone, 2 vols. (Washington: Gales \& Seaton, 1826), 1:141. Tone's allusion to Jonathan Swift's fictional island of Blefescu was commonly understood to be a reference to Belfast. See for example Robert Magill Young, Historical Notices of Old Belfast and Its Vicinity (Belfast: Marcus Ward, 1896), 181.

15. Nancy J. Curtin, The United Irishmen: Popular Politics in Ulster and Dublin, 1791-1798 (Oxford: Clarendon Press, 1998), esp. 202-11. See also Gillian O'Brien, “'Spirit, Impartiality and Independence': The Northern Star, 1792-1797," Eighteenth-Century Ireland 13 (1998): 7-23.

16. Tone, Life of Theobald Wolfe Tone, 1:128.

17. Government surveillance records of United Irish membership in Ulster in May 1797 list 117,917 for the entire province, of which 48,869 were from Antrim and Down; see Curtin, United Irishmen, 125.

18. Nancy J. Curtin, "The United Irish Organisation in Ulster: 1795-8," in David Dickson, Dáire Keogh and Kevin Whelan, eds., The United Irishmen: Republicanism, Radicalism and Rebellion (Dublin: Lilliput Press, 1993), 209-21.

19. See A. T. Q. Stewart, The Summer Soldiers: The 1798 Rebellion in Antrim and Down (Belfast: Blackstaff Press, 1995).

20. Tone, Life of Theobald Wolfe Tone, 1:51-2.

21. Allan Blackstock, Loyalism in Ireland, 1789-1829 (Woodbridge: Boydell, 2007), 99-105. For examples of such loyalist declarations see S. Shannon Millin, Additional Sidelights on Belfast History (Belfast and London: W. and G. Baird, 1938), 101-2.

22. Castlereagh to the Duke of Portland, June 3, 1799, in Charles Vane, ed., Memoirs and Correspondence of Viscount Castlereagh, Second Marquess of Londonderry, 12 vols. (London: H. Colburn, 1850), 2:326.

23. Cornwallis to the Duke of Portland, October 22, 1799, in Charles Ross, ed., Correspondence of Charles, First Marquis Cornwallis, 3 vols. (London: John Murray, 1859) (hereafter Cornwallis Correspondence), 3:141.

24. Geoffrey Bolton, The Passing of the Irish Act of Union: A Study in Parliamentary Politics (London: Oxford University Press, 1966), 135-39. 
25. See Ruán O'Donnell, Robert Emmet and the Rising of 1803 (Dublin: Irish Academic Press, 2003), 44-46 and 113-14; Marianne Elliott, Robert Emmet: The Making of a Legend (London: Profile, 2003), 64.

26. Ian McBride, "Ulster Presbyterians and the Passing of the Act of Union," in Patrick M. Geoghegan, Michael Brown and James Kelly, eds., The Irish Act of Union, 1800: Bicentennial Essays (Dublin and Portland: Irish Academic Press, 2003), 68-83 (esp. 72-76).

27. Cornwallis to the Duke of Portland, February 23, 1799, in Cornwallis Correspondence, 3:67.

28. Cornwallis to the Duke of Portland, January 21, 1800, in ibid., 3:168-69.

29. Cornwallis to the Duke of Portland, June, 28 1800, in ibid., 3:283.

30. James G. Patterson, In the Wake of the Great Rebellion: Republicanism, Agrarianism and Banditry in Ireland after 1798 (Manchester and New York: Manchester University Press, 2008), 13-79.

31. A. R. Holmes, "Covenanter Politics: Evangelicalism, Political Liberalism and Ulster Presbyterians, 1798-1914," English Historical Review 125, no. 513 (2010): 346.

32. In a seminal essay on the "politics of memory", which charted the "shifting and contested meaning of 1798 after 1798," Kevin Whelan labeled the aftermath of the rebellion among Ulster Presbyterians a "retreat from revolution"; Kevin Whelan, The Tree of Liberty: Radicalism, Catholicism and the Construction of Irish Identity 1760-1830 (Cork: Cork University Press, 1996), 153-55.

33. John Bew, The Glory of Being Britons: Civic Unionism in Nineteenth-Century Belfast (Dublin: Irish Academic Press, 2009), esp. 61-68.

34. Jim Smyth, "The 1798 Rebellion in Its Eighteenth-Century Contexts," in Jim Smyth, ed., Revolution, Counter-Revolution, and Union: Ireland in the 1790s (Cambridge: Cambridge University Press, 2000), 17.

35. Brian Walker, "1641, 1689, 1690 and All That: The Unionist Sense of History," Irish Review 12 (June 1992): 56-64 (esp. 58). In essence, late-nineteenthcentury unionist historiography was not all that new and substantially drew on previously established traditions of Protestant loyalist commemoration; see T. C. Barnard, "The Uses of 23 October 1641 and Irish Protestant Celebrations," English Historical Review 106, no. 421 (1991): 889-920; James Kelly, “The Glorious and Immortal Memory': Commemoration and Protestant Identity in Ireland 1660-1800," in Proceedings of the Royal Irish Academy 94C, no. 2 (1994): 25-52; James McConnel, "Remembering the 1605 Gunpowder Plot in Ireland, 1605-1920," Journal of British Studies 50, no. 4 (2011): 863-91.

36. See Gillian McIntosh, The Force of Culture: Unionist Identities in TwentiethCentury Ireland (Cork, 1999: Cork University Press), 23-24. 
37. Alvin Jackson, “Unionist History (I)," Irish Review 7 (December 1989): 63.

38. Ernest W. Hamilton, The Soul of Ulster (New York: E. P. Dutton, 1917), 89-106. In contrast, Hamilton's subsequent history of the 1641 rebellion featured a "detailed account of the massacres," which he considered "events which-more than any others-have helped to shape the destinies of the province"; see Ernest W. Hamilton, The Irish Rebellion of 1641 (London: J. Murray, 1920).

39. Ian McBride, "Memory and Forgetting: Ulster Presbyterians and 1798," in Bartlett, Dickson, Keogh and Whelan, eds., 1798, 478-96. See also Brian Walker's essay "The Lessons of Irish History: The Continuing Legacy of the 1798 Rebellion and the United Irishmen," in Brian Walker, Past and Present: History, Identity and Politics in Ireland (Belfast: Institute of Irish Studies, Queen's University, 2000), 29-77.

40. For an elaboration of the concept of vernacular historiography, with reference to the social memory of 1798 in the West of Ireland, see Guy Beiner, Remembering the Year of the French: Irish Folk History and Social Memory (Madison: Wisconsin University Press, 2006).

41. John Tosh, The Pursuit of History: Aims, Methods and New Directions in the Study of Modern History (Essex and New York: Longman, 1984), 186. The metaphor of a Word document, without records of previous drafts, may be a more suitable contemporary metaphor.

42. For popular reading habits in Ulster, see J. R. R. Adams, The Printed Word and the Common Man: Popular Culture in Ulster 1700-1900 (Belfast: Institute of Irish Studies, Queen's University, 1987).

43. David Gross, The Past in Ruins: Tradition and the Critique of Modernity (Amherst: University of Massachusetts Press, 1992), 107-19.

44. See Beiner, Remembering the Year of the French, 313-21 (esp. 319).

45. Sir Richard Musgrave to George Lenox Conyngham, April 27, 1799; Public Record Office of Northern Ireland (hereafter PRONI), MS D1449/12/292. Defenders refers to a principally Catholic secret society, which cooperated with the United Irishmen in 1798.

46. George Lenox-Conyngham to Sir Richard Musgrave, c. April-May 1799; PRONI, MS D1449/12/292A.

47. Richard Musgrave, Memoirs of the Different Rebellions in Ireland, from the Arrival of the English (Dublin: Robert Marchbank, 1802; 3rd ed.), 2 vols. See also Whelan, The Tree of Liberty, 135-38 ("The Matrix of Memory"); James Kelly, Sir Richard Musgrave, 1746-1818: Ultra-Protestant Ideologue (Dublin: Four Courts Press, 2009), 90-125 (esp. 115 and 119-20).

48. S. M. S., "Sketch of a Ramble to a[N]Trim (Concluded)," Belfast Monthly Magazine 3, no. 12 (1809): 5-6. For additional references to 1798 by the same 
writer see "Sketch of a Ramble to Antrim, Taken July 10th, 1[8]08," ibid. 2, no. 11 (1809): 424-5; “An Account of Island Magee, Taken in 1809," ibid., 3, no. 13 (1809): 105; “A Ramble in 1809," ibid., 6, no. 32 (1811): 183; "Ramble in 1810," ibid., 8, no. 45 (1812): 265; “Ramble in 1810 (Continued), " ibid. 8, no. 46 (1812): 369.

49. John Gamble, A View of Society and Manners in the North of Ireland, in the Summer and Autumn of 1812 (London: C. Cradock and W. Joy, 1813); John Gamble, Charlton, or, Scenes in the North of Ireland, a Tale (London; Baldwin, Cradock and Joy, 1823), 3 vols. See also Breandán Mac Suibhne, “Afterworld: The Gothic Travels of John Gamble (1770-1831)," Field Day Review 4 (2008): 62-113. For a critical edition of Gamble's travel writings, see John Gamble, Society and Manners in Early Nineteenth-Century Ireland, ed. Breandán Mac Suibhne (Dublin: Field Day, 2011).

50. James Orr, Poems on Various Subjects (Belfast: Smyth and Lyons, 1804; reprinted, Belfast: William Mullan and Son, 1935), 33; Francis Boyle, Miscellaneous Poems (Belfast: D. and S. Lyons, 1811), 154-58. See also John Hewitt, Rhyming Weavers and other Country Poets of Antrim and Down (Belfast: Blackstaff Press, 1974); Donald Harman Akenson and W. H. Crawford, Local Poets and Social History: James Orr, Bard of Ballycarry (Belfast: Public Records Office Northern Ireland, 1977); Carol Baraniuk, "James Orr: Ulster-Scot and Poet of the 1798 Rebellion," Scottish Studies Review 6, no. 1 (2005): 22-32; Andrew R. Holmes, "Presbyterian Religion, Poetry and Politics in Ulster, c. I770-1850," in Frank Ferguson and Andrew R. Holmes, eds., Revising Robert Burns and Ulster: Literature, Religion and Politics, c. 1770-1920 (Dublin: Four Courts Press, 2009), 37-63.

51. Henry Joy, Historical Collections Relative to the Town of Belfast: From the Earliest Period to the Union with Great Britain (Belfast: G. Berwick, 1817), x.

52. See "Prospectus," $\mathrm{i}-\mathrm{ii}$, and introductory note "To Correspondents" in first issue of Belfast Magazine and Literary Journal (1825).

53. Iota [James Thomson], "Recollections of the Battle of Ballynahinch by an Eye Witness," Belfast Magazine and Literary Journal 1, no. 1 (1825): 56-64. The author, who would later be known mainly as the father of William Thomson, Lord Kelvin, would often speak to his family about the time of the rebellion, which according to his daughter "left a deep impression on my father's mind"; see Andrew R. Holmes, "Professor James Thomson Sr. and Lord Kelvin: Religion, Science, and Liberal Unionism in Ulster and Scotland," Journal of British Studies, 50, no. 1 (2011): 105 .

54. E. [Samuel Edgar], "Recollections of 1798," Belfast Magazine and Literary Journal 1, no. 4 (1825): 540-48. 
55. James McHenry, Patrick: A Poetical Tale Founded on Incidents Which Took Place in Ireland during the Unhappy Period of 1798 (Glasgow: D. M'Kenzie, 1810). For contemporary reception see Belfast Monthly Magazine, May 31, 1810, 348.

56. James McHenry, The Insurgent Chief; or, the Pikemen of '98: A Romance of the Irish Rebellion. To Which is Added an Appendix, Containing Biographical Memoirs of the Principle Characters and Descriptive of the Scenery of the Work (1824; Belfast: John Henderson, 1844). The first two chapters originally appeared in the American Monthly Magazine 1, no. 1 (1824): 30-39, and no. 2 (1824): 147-58. Later that year, the entire novel was published in Philadelphia as a book, which was reprinted in London. See also Charles Fanning, The Irish Voice in America: 250 Years of Irish-American Fiction (1990; Lexington: University Press of Kentucky, 2000), 46-50.

57. The novel was eventually adapted by James Allen into a play, which was published in Dublin in 1867. See Rolf Loeber and Magda Loeber, A Guide to Irish Fiction, 1650-1900 (Dublin: Four Courts Press, 2005), 825.

58. William Hamilton Maxwell, O’Hara; or, 1798 (London: J. Andrews, 1825), 2 vols. Published twenty years later, Maxwell's historical account of the rebellion in the north described the "folly of precipitating into action tumultuary masses of men" and concluded: "On the Northerns the lesson was not lost, and the immediate pacification of the country resulted"; William Hamilton Maxwell, History of the Irish Rebellion in 1798; with Memoirs of the Union, and Emmett's Insurrection in 1803 (London: Baily, 1845), 204-19. For Maxwell's increasing conservativeness when returning to address the topic of 1798 in the 1840s, see Jim Shanahan, "Fearing to Speak: Fear and the 1798 Rebellion in the Nineteenth Century," in Kate Hebblethwaite and Elizabeth McCarthy, eds., Fear: Essays on the Meaning and Experience of Fear (Dublin: Four Courts Press, 2007), 31-46.

59. Published in anon. [E. E. Crowe], Yesterday in Ireland (London: Henry Colburn, 1829), 2:291-327 and vol. 3.

60. C. H. Teeling to Lord Cornwallis, November 4, 1798, National Library of Ireland MS 17863 (10); cited in C. J. Woods, "Teeling, Charles Hamilton," in James McGuire and James Quinn (eds.), Dictionary of Irish Biography (Cambridge: Cambridge University Press, 2009); available at http://dib.cambridge. org/viewReadPage.do?articleId=a8486.

61. Charles Hamilton Teeling, Personal Narrative of the "Irish Rebellion" of 1798 (London: Henry Colburn, 1828), esp. 203-263; Teeling, Sequel to Personal Narrative of the "Irish Rebellion" of 1798 (Belfast: John Hodgson, 1832), esp. 25-80.

62. Memoir written by James Boyle for Grange of Dundermot, County Antrim (September 1835) and published in Angélique Day and Patrick McWilliams, eds., Ordnance Survey Memoirs of Ireland, vol. 13 (Belfast: Institute of Irish Studies, 
Queen's University, 1992), 32. Boyle made similar observations in other parishes, such as Island Magee (1840), in ibid., 10 (1991): 41; Dunaghy (1835), in ibid. 13:14; and Rashee (1835), in ibid., 32 (1995): 140; cf. similar comments by Lieutenant J. Chaytor regarding the village of Kells in the parish of Connor (February 1833), in ibid., 19 (1993): 24.

63. Gillian Smith, “'An Eye on the Survey': Perceptions of the Ordnance Survey in Ireland 1824-1842," History Ireland 9, no. 2 (2001): 41. For a discussion of the concept of commemorative vernacular landscape with reference to 1798 in the West of Ireland, see Beiner, Remembering the Year of the French, 208-30.

64. Gillian M. Doherty, The Irish Ordnance Survey: History, Culture and Memory (Dublin: Four Courts Press, 2006), 183. Following government concerns regarding recognition accorded to indigenous customs, the topographical department overseeing this project was shut down and the publication of its memoirs terminated. See J. H. Andrews, A Paper Landscape: The Ordnance Survey in Nineteenth-Century Ireland (Oxford: Clarendon Press, 1975), 123-29 and 156-68; For a critique of the survey as an agent of cultural colonization see Stiofán Ó Cadhla, Civilizing Ireland: Ordnance Survey 1824-1842, Ethnography, Cartography, Translation (Dublin: Irish Academic Press, 2007).

65. Samuel McSkimin, The History and Antiquities of the County of the Town of Carrickfergus, from the Earliest Records to the Present Time, in Four Parts (Belfast: Hugh Kirk Gordon, 1811), 85.

66. Letter from James Hope to R. R. Madden, undated; reproduced in Richard Robert Madden, The United Irishmen: Their Lives and Times (Dublin: James Duffy, 1846), 3rd ser., vol. 1:223.

67. For the manuscript see Royal Irish Academy MS 24 Q 22. The comment on his preparations appears in the preface to the revised edition. A new edition, which includes previously unpublished notes, was put together in the early twentieth century by his great-granddaughter Elizabeth McCrum, a fellow of the Royal Society of Arts; Samuel McSkimin, The History and Antiquities of the County of the Town of Carrickfergus, from the Earliest Records till 1839 (Belfast: Mullan \& Son, James Cleeland, Davidson and McCormack, 1909), esp. 95-100. In a short biographical memoir, McCrum contested McSkimin's alleged hatred of the United Irishmen; see ibid., 525-26.

68. "Samuel M'Skimmin, Historian of Carrickfergus," Nation, March 4, 1843, 329.

69. Samuel McSkimin, Annals of Ulster; or, Ireland Fifty Years Ago (Belfast: John Henderson, 1849); reissued shortly after by the Belfast bookseller John Mullan as History of the Irish Rebellion in the Year 1798 particularly in Antrim, Down and Derry (Belfast: John Mullan, 1853). 
70. See Mary McNeill, The Life and Times of Mary Ann McCracken 1770-1866: A Belfast Panorama (1960; Belfast: Blackstaff Press, 1988), 305-7.

71. Letter from M. A. McCracken to R. R. Madden, Belfast, October 15, 1844, Trinity College Dublin, MS 873/156. Nelly Rabb to M. A. McCracken, Ballysallagh, November 18, 1843 ("mass of fabrication"), and M. A. McCracken to R. R. Madden, Belfast, July 2, 1844 ("falsehoods and misrepresentations"), ibid., MS 873/627 and 873/155 (respectively). See also Anna McCleary, "Life of Mary Ann M'Cracken, Sister of Henry Joy M'Cracken," in Young, Historical Notices of Old Belfast, 197.

72. Spread over multiple "series" and "editions," the publication of Madden's magnum opus was a convoluted affair; see C. J. Woods, “R. R. Madden, Historian of the United Irishmen," in Bartlett, Dickson, Keogh and Whelan, eds., 1798, 497-511. A comprehensive new edition published in the United States in the early twentieth century added an index volume; Richard Robert Madden, The United Irishmen: Their Lives and Times (New York: The Catholic Publication Society, 1916), 12 vols.

73. Richard Robert Madden, Antrim and Down in '98 (Glasgow: R. \& T. Washbourne, c. 1900).

74. See Classon Porter Papers, PRONI, MS D 2009.

75. Porter had also acquired some of McSkimin's manuscripts. His notes are reproduced verbatim in Robert Magill Young, Ulster in '98: Episodes and Anecdotes (Belfast: Marcus Ward, 1893), esp. 1-60.

76. See Descriptive Catalogue of the Collection of Antiquities, and Other Objects, Illustrative of Irish History, Exhibited in the Museum, Belfast, on the Occasion of the Twenty-Second Meeting of the British Association for the Advancement of Science, September, 1852 (Belfast: Archer \& Sons, 1852), preface and 13, 17, 27, 43, 52. See also M., "The Archæology of Ulster," Ulster Journal of Archaeology, ser. 1, 1 (1853): 6-7.

77. Republished as Old Ballymena: A History of Ballymena during the 1798 Rebellion, 2nd ed. (Ballymena: Ballymena Observer, 1938).

78. M'Comb's Guide to Belfast: The Giant's Causeway and the Adjoining Districts of the Counties of Antrim and Down, with an Account of the Battle of Ballynabinch, and the Celebrated Mineral Waters of That Neighbourhood (Belfast: William McComb, 1861), quotations from 142-43; "Bessie Grey" in The Poetical Works of William McComb (London: Hamilton Adams, 1864), 357-58. For McComb's anti-nationalist politics, see William McComb, The Repealer Repulsed, ed. Patrick Maume (Dublin: University College Dublin Press, 2003; orig. ed. Belfast: William McComb, 1841). His acclamation as the laureate of Presbyterianism dates to the late nineteenth century; see Robert Jeffrey, The Indian Mission of the Irish 
Presbyterian Church: A History of Fifty Years of Work in Káthiáwár and Gujarat (London: Nesbitt, 1890), 63.

79. George Benn, A History of the Town of Belfast: From the Earliest Times to the Close of the Eighteenth Century, 2 vols. (London: Marcus Ward, 1877), 1:666. The original of this local history edition, published twenty-five years after 1798, included only very brief mention of the rebellion in Ulster; see anon. [George Benn], The History of the Town of Belfast (Belfast: Marcus Ward, 1823), 63.

80. T. C. S. Corry, The Battle of Antrim: A Reminiscence of 1798 (Belfast: J. Henderson, 1875); idem, Irish Lyrics, Songs \& Poems (Belfast: D. \& J. Allen, 1879); 2nd ed. (Belfast: J. Robb, 1884), 17-24 and 113-14.

81. For the program of the "Irish Diorama" see T. C. S. Corry, Ireland: Its Scenery, Music, and Antiquities, 3rd ed. (Dublin: Hodges, Smith, 1866). When exhibited in Belfast in 1865, this celebration of "Ireland, that bright and valuable gem in the British Crown" received glowing reviews; see Belfast Morning News, January 4, 1865; Ulster Observer, January 5, 1865; Banner of Ulster, January 5, 1865; Belfast Northern Whig, January 13, 1865; Belfast News-Letter, January 14, 1865.

82. See biographical entry and accompanying comments by Kenneth Robinson in the most recent edition of the novel: W. G. Lyttle, Betsy Gray or, Hearts of Down: A Tale of '98 (Belfast: Ullans Press, 2008), 159-64. McClelland's comment appears in his preface to a 1968 edition issued in Newcastle, County Down.

83. Rosa Mulholland, Hester's History, 2 vols. (London: Chapman and Hall, 1869), initially serialized at the request of Charles Dickens in All the Year Round (August 29-November 28, 1868); Mrs Charles Montague Clarke, Strong as Death, 3 vols. (London: Tinsley Bros., 1875); Mary Damant, Peggy: A Tale of the Irish Rebellion (London: W. H. Allen, 1887).

84. H. C. G. Matthew, ed., The Gladstone Diaries, 12 vols. (Oxford: Clarendon Press, 1968), 12:215.

85. For a more elaborate consideration of this development see Guy Beiner, "Recollecting the Turnout: Antiquarians and Folk History in Belfast Circa 1898," in Ríonach uí Ógáin, William Nolan and Éamonn Ó hÓgáin, eds., Sean, Nua agus Sioraiocht: Féilscríbbinn in ómós do Dháithí Ó hÓgáin (Old, new and eternity: Festschrift in honor of Dáithí Ó hÓgáin) (Dublin: Coiscéim, 2012), 436-49.

86. "Prospectus," Ulster Journal of Archaeology, ser. 2., 1, no. 1 (1894): 1.

87. J. S. Crone, "Francis Joseph Bigger: Memoir," in J. S. Crone and F. C. Bigger, eds., In Remembrance: Articles er Sketches, Biographical, Historical, Topographical, by Francis Joseph Bigger, M.A., M.R.I.A., F.R.S.A.I. (Dublin: Talbot Press, 1927), xxxi-ii.

88. Francis Joseph Bigger, Remember Orr (Dublin: Maunsel, 1906), 6. Bigger's papers at the Belfast Central Library include over fifty files of manuscripts 
on the United Irishmen, among them a series of biographies of "The Northern Leaders of '98," which have remained mostly unpublished. See Roger Dixon, "Heroes for a New Ireland: Francis Joseph Bigger and the Leaders of the '98," in Trefor M. Owen, ed., From Corrib to Cultra: Folklife Essays in Honour of Alan Gailey (Belfast: Institute of Irish Studies, in association with the Ulster Folk and Transport Museum, 2000), 29-37. My thanks to the librarian for permission to consult the manuscripts.

89. R. M. Young, Ulster in '98: Episodes and Anecdotes (Belfast: Marcus Ward, 1893), preface.

90. W. S. Smith, Memories of '98 (Belfast: Marcus Ward, 1895); serialized in the Ulster Journal of Archaeology, ser. 2, 1 (1895): 133-42, 210-17, 284-89, and 2 (1896): 86-91. Several years earlier, Smith had written a short account of the 1798 Rebellion in Antrim, which included information received from "a very old man named John Kilpatrick of Rathmore, who died in the year 1874, [and who] used to relate several incidents connected with the battle"; W. S. Smith, Historical Gleanings in Antrim and Neighbourhood (Belfast: Alex, Mayne \& Boyd, 1888), 16-26 (esp. 24-26).

91. W. T. Latimer, Ulster Biographies, Relating Chiefly to the Rebellion of 1798 (Belfast: James Cleeland, William Mullan \& Son, 1897). See also W. T. Latimer, A History of the Irish Presbyterians (1893; James Cleeland and William Mullan: Belfast, 1902), 395-402.

92. See Georges Denis Zimmerman, Songs of Irish Rebellion: Irish Political Street Ballads and Rebel Songs, 1780-1900 (1966; Dublin: Four Courts Press, 2002), 158-59.

93. See Richard Harp, "The Shan Van Vocht (Belfast 1896-1899) and Irish Nationalism," in Éire-Ireland 24 (1989): 42-52; Virginia Crossman, "The Shan Van Vocht: Women, Republicanism, and the Commemoration of the 1798 Rebellion," Eighteenth-Century Life 22, no. 3 (1998): 128-39; Catherine Morris, "Becoming Irish? Alice Milligan and the Revival," Irish University Review 33, no. 1 (2003): 79-98; Eugene McNulty, "The Place of Memory: Alice Milligan, Ardrigh, and the 1898 Centenary," Irish University Review 38, no. 2 (2008): 203-21.

94. M. T. Pender, The Green Cockade: A Tale of Ulster in 'Ninety-Eight(Dublin: Martine Lester, 1898). In addition, a collection of short stories by James Moran published that year included "Maureen's Find," which was set in Ulster after the Battle of Antrim; J. J. Moran, Stories of the Irish Rebellion, 1798 (Aberdeen: Moran, and London: Simpkin, 1898), 111-21. The centennial year also saw the reissue of previously published novels, including a cheap edition of Mrs Charles Montague [Marion] Clarke, Strong as Death: A Story of the Irish Rebellion (1875; Aberdeen: Moran, 1898).

95. See Smith, Memories of '98, 8-11, 21, 28-29, 34-35. 
96. Rev. Henry Montgomery, "Outlines of the History of Presbyterianism in Ireland," Irish Unitarian Magazine 2 (1847): 329; reproduced in John A. Crozier, The Life of the Rev. Henry Montgomery L. L. D., Dunmurry, Belfast; With Selections from His Speeches and Writings, 2 vols. (London: E. T. Whitfield and Simpkin Marshall; Belfast: W.H. Greer, 1875), 1:10.

97. McSkimin, Annals of Ulster, 112. See also Samuel McSkimin, "Secret History of the Irish Insurrection of 1803," Fraser's Magazine for Town and Country 14, no. 83 (1836): 554-57; Belfast \& Its Environs: Or, Stranger's Guide (Belfast: John Henderson, and Dublin: James McGlashan, 1855), 15; Old Ballymena, 36-37; Young, Ulster in '98, 19-21, 23, 43, 48, 74; Smith, Memories of '98, 14, $16,29,41,45,53,61,69$.

98. Timothy O'Keefe, “The 1898 Efforts to Celebrate the United Irishmen: The '98 Centennial," Éire-Ireland 23, no. 2 (1988): 63-64; A. C. Hepburn, Catholic Belfast and Nationalist Ireland in the Era of Joe Devlin, 1871-1934 (Oxford: Oxford University Press, 2008), 76-82.

99. Owen McGee, The IRB: The Irish Republican Brotherhood from the Land League to Sinn Fein (Dublin: Four Courts Press, 2005), 243 and 251-54.

100. Anna Kinsella, "1798 Claimed for Catholics: Father Kavanagh, Fenians and the Centenary Celebrations," in Dáire Keogh and Nicholas Furlong, eds., The Mighty Wave: The 1798 Rebellion in Wexford (Dublin: Four Courts Press, 1996), 139-55.

101. David Hempton and Myrtle Hill, Evangelical Protestantism in Ulster Society 1740-1890 (London and New York: Routledge, 1992), 141-83.

102. See Alvin Jackson, Ireland 1798-1998: Politics and War (Oxford: Blackwell, 2010), 212-24.

103. Belfast News-Letter, June 2, 1898.

104. Peter Collins, Who Fears to Speak of'98? Commemoration and the Continuing Impact of the United Irishmen (Belfast: Ulster Historical Foundation, 2004), $31-45$.

105. Peter Stewart, "The Destruction of Statues in Late Antiquity," in Richard Miles, ed., Constructing Identities in Late Antiquity (London and New York: Routledge, 1999), 167.

106. Charles W. Hedrick, History and Silence: Purge and Rebabilitation of Memory in Late Antiquity (Austin: University of Texas Press, 2000), 93.

107. Among F. J. Bigger's publications on the United Irishmen in the decade following the centenary can be found: Remember Orr (Dublin: Maunsel, 1906); Rody MacCorly: "Who Fears to Speak of'98?”(Belfast: F. J. Bigger, 1907); “Memorials of the Patriot Dead: MacCorly, Dickson, MacCracken," Ulster Journal of Archaeology 15, no. 2/3 (1909): 93-95. 
108. S. R. Keightley, The Pikemen: A Romance of the Ards of Down (London: Hutchinson, 1903); Louie Bennett, A Prisoner of his Word: A Tale of Real Happenings (Dublin: Maunsel, 1908); George A. Birmingham, The Northern Iron (Dublin: Maunsel, 1907); Andrew James, Ninety-Eight and Sixty Years After (Edinburgh and London: William Blackwood and Sons, 1911). Two of the stories in the James collection were originally issued in Blackwood's Magazine 181, no. 1096 (February 1907): 197-207 (“Nabob Castle: A Legend of Ulster”) and no. 1099 (May 1907): 628-641 (“The Last O'Hara”). For a critical edition see Andrew James, The Nabob: A Tale of Ninety-Eight, notes and afterword by John Wilson Foster (Dublin: Four Courts Press, 2006).

109. P. J. Bourke, “The Northern Insurgents: Ulster in 1798," Journal of Irish Literature 13, no. 1 and 2 (1984): 7-74; idem, "For the Land She Loved," in Cheryl Herr, ed., For the Land They Loved: Irish Political Melodramas, 1890-1925 (Syracuse: Syracuse University Press, 1993), 311-59. A decade earlier, Bourke's mentor-the English dramatist James William Whitbread-had written a melodrama on Henry Joy McCracken titled The Ulster Hero, which was produced at the Queen's Theatre in 1903.

110. J. C. McDermott, An Enriching Life (Belfast: Self-published, 1979), 25.

111. Irish National Folklore Collection, University College Dublin Main Manuscripts Collection, MSS 1360: 8; 1361: 109-10; 1362: 114; 1364: 206-12 and 262-22; 1365: 284; 1386: 153-59; 1387: 229-41; 1389: 189; 1390: 234; 1413: 22, 168, 203 and 278-79; 1432: 11, 141, 167, 238-39, 277 and 283; 1470: 19 and 195-207. My thanks to the Director of the National Folklore Collection at University College Dublin for permission to consult and cite this material.

112. Ulster Folk and Transport Museum MSS V-12-5: 11-13 and 46-47; V-16-2: 25, 65 and 83-84. My thanks to Linda May Ballard of the Ulster Folk and Transport Museum for allowing me access to this material.

113. Mourne Observer, July 1, 1967-October 18, 1968; republished in W. G. Lyttle, Betsy Gray or, Hearts of Down: A Tale of'98 (Newcastle Co. Down: Mourne Observer, 1968), appendix.

114. Jay Winter, "Thinking about Silence," in Efrat Ben-Ze'ev, Ruth Ginio and J. M. Winter, eds., Shadows of War: A Social History of Silence in the Twentieth Century (Cambridge and New York: Cambridge University Press, 2010), 29-30.

115. Queen's University, Belfast, Thomas Carnduff Archive, MS 21/1/5. See also John Gray, ed., Thomas Carnduff: Life and Writings (Belfast: Lagan Press, 1994), 34-36, 113, 131-33.

116. Cathal O'Byrne, As I Roved Out (Belfast: Irish News, 1946); see also Richard Kirkland, Cathal O'Byrne and the Northern Revival in Ireland, 1890-1960 (Liverpool: Liverpool University Press, 2006). 
117. Jack Loudan, Henry Joy McCracken: A Play in Three Acts (Dublin: New Frontiers Press, 1946).

118. Northern Ireland cabinet discussion, September 8, 1948, PRONI, CAB 4/761/9.

119. Collins, Who Fears to Speak, 65-75.

120. In particular Heaney's poem "Linen Town” (1969) and his BBC-commissioned verse-play "Munro" (1970); see John Hobbs, "United Irishmen: Seamus Heaney and the Rebellion of 1798," Canadian Journal of Irish Studies 21, no. 2 (1995): 38-43; John F. Healy, "Seamus Heaney and the Croppies: 1798 and the Poet's Early Political Inclinations," in Brian Coates, Joachim Fischer and Patricia A. Lynch, eds., Back to the Present, Forward to the Past: Irish Writing and History since 1798 (Amsterdam and New York: Rodopi, 2006), 1:53-65.

121. Sam Hanna Bell, A Man Flourishing (London: Gollancz, 1973); see also Richard Mill, "Sam Hanna Bell, 1798 and the Death of Protestant Radicalism," in P. J. Mathews, ed., New Voices in Irish Criticism (Dublin: Four Courts Press, 2000), 116-22.

122. Stewart Parker, Three Plays for Ireland (Birmingham: Oberon Books, 1989); see also Marilynn Richtarik, "Living in Interesting Times: Stewart Parker's Northern Star," in John P. Harrington and Elizabeth J. Mitchell, eds., Politics and Performance in Contemporary Northern Ireland (Amherst: University of Massachusetts Press, 1999), 7-28.

123. John Harold Hewitt, Two Plays: The McCrackens; the Angry Doves (Belfast: Lagan Press, 1999). As Damian Smyth states in his introduction, in absence of documentation, the date of composition of The McCrackens cannot be determined.

124. Gary Mitchell, Tearing the Loom; and, in a Little World of Our Own (London: Nick Hern Books, 1998).

125. Andrew Schaap, Political Reconciliation (London and New York: Routledge, 2005), 124-37.

126. Collins, Who Fears to Speak, 84-121. For criticism of bicentennial reinterpretations of 1798 influenced by contemporary politics of reconciliation, see Roy Foster's essay "Remembering 1798," in R. F. Foster, The Irish Story: Telling Tales and Making It up in Ireland (London and New York: Allen Lane, 2001), $211-324$.

127. Roberto Cubelli, "A New Taxonomy of Memory and Forgetting," in Sergio Della Sala, ed., Forgetting (Hove and New York: Psychology Press, 2010), 42 .

128. Paul Ricoeur, Memory, History, Forgetting (Chicago: University of Chicago Press, 2004), 418 and 426.

129. See the essays in Ben-Ze'ev, Ginio and Winter, eds., Shadows of War. 
130. Hermann Ebbinghaus, Memory: A Contribution to Experimental Psychology, trans. Henry A. Ruger and Clara E. Bussenius (New York: Dover Publications, 1964); orig. Über das Gedchtnis: Untersuchungen zur experimentellen Psychologie (Leipzig: Duncker \& Humblot, 1885).

131. Graham Dawson, Making Peace with the Past? Memory, Trauma and the Irish Troubles (Manchester: Manchester University Press, 2007), 316.

132. See Paul Connerton, How Modernity Forgets (Cambridge and New York: Cambridge University Press, 2009); David Gross, Lost Time: On Remembering and Forgetting in Late Modern Culture (Amherst: University of Massachusetts, 2000), 133-53.

133. Collins, Who Fears to Speak, 170-72. 